\title{
Age-Related Changes of Some Trace Element Contents in Intact Thyroid of Females Investigated by Energy Dispersive X-Ray Fluorescent Analysis
}

\author{
Vladimir Zaichick ${ }^{1 *}$ and Sofia Zaichick ${ }^{2}$ \\ ${ }^{1}$ Radionuclide Diagnostics Department, Medical Radiological Research Centre, Russia \\ ${ }^{2}$ Feinberg School of Medicine, Northwestern University, USA
}

\begin{abstract}
A prevalence of thyroid dysfunction is higher in the elderly as compared to the younger population. An excess or deficiency of trace element contents in thyroid play important role in goitro-and carcinogenesis of gland. The variation with age of the mass fraction of six trace elements $(\mathrm{Br}, \mathrm{Cu}, \mathrm{Fe}, \mathrm{Rb}, \mathrm{Sr}$, and $\mathrm{Zn}$ ) in intact (normal) thyroid of 33 females (mean age 54.5 years, range 3.5-87) was investigated by $109 \mathrm{Cd}$ radionuclide-induced energy dispersive X-ray fluorescent analysis. Mean values \pm standard error of mean for mass fractions $(\mathrm{mg} / \mathrm{kg}$, on dry-mass basis) of the trace elements studied were: $\mathrm{Br} 20.4 \pm 2.6, \mathrm{Cu} 4.18 \pm 0.43$, Fe $223 \pm 21, \mathrm{Rb} 6.64 \pm 0.48$, Sr $4.67 \pm 0.78$, and $\mathrm{Zn} 89.0 \pm 8.4$. This work revealed that there is a significant tendency for an increase in $\mathrm{Rb}$ and $\mathrm{Zn}$ mass fraction in normal female thyroid from age 41 years to the nine decade. Therefore, a goitrogenic and carcinogenic effect of excessive $\mathrm{Rb}$ and $\mathrm{Zn}$ level in the thyroid of old females may be assumed.
\end{abstract}

Keywords

Thyroid, Trace elements, Age-related changes, Energy dispersive X-ray fluorescent analysis

Abbreviations

109 Cd EDXRF: 109 Cd Radionuclide-Induced Energy-Dispersive X-Ray Fluorescence Analysis; CRM/SRM: Certified/ Standard Reference Materials; IAEA: International Atomic Energy Agency

\section{Introduction}

The endocrine organs, including the thyroid gland, undergo important functional changes during aging and a prevalence of thyroid dysfunction is higher in the elderly as compared to the younger population $[1,2]$. Advancing age is known to influence the formation of adenomatous goiter and thyroid cancer [3]. The prevalence of thyroid nodules is increased in the elderly, reaching a frequency of nearly $50 \%$ by the age of 65 [4]. Both prevalence and aggressiveness of thyroid cancer increase with age [2]. Women are affected by thyroid nodule and cancer two to five times more often than men [2-5].

Aging is a complex process involving biochemical and morphologic changes in single cells, in organs, and in the whole organism. One of the most generally accepted explanations of how aging occurs at the molecular level is the oxidative stress hypothesis [6]. Reactive Ox- ygen Species (ROS) are widely considered to be a causal factor not only in aging but in a number of pathological conditions, including carcinogenesis. Aging, considered as an impairment of body functions over time, caused by the accumulation of molecular damage in DNA, proteins and lipids, is also characterized by an increase in intracellular oxidative stress due to the progressive de-

*Corresponding author: Vladimir Zaichick, Professor, Radionuclide Diagnostics Department, Medical Radiological Research Centre, 4 Korolyev St, MRRC, Obninsk 249036, Kaluga Region, Russia, Tel: +7-(48439)-60289, E-mail: vezai@obninsk.com

Received: March 24, 2017; Accepted: June 08, 2017; Published online: June 12, 2017

Citation: Zaichick V, Zaichick S (2017) Age-Related Changes of Some Trace Element Contents in Intact Thyroid of Females Investigated by Energy Dispersive X-Ray Fluorescent Analysis. Trends Geriatr Healthc 1(1):31-38

Copyright: (C 2017 Zaichick V, et al. This is an open-access article distributed under the terms of the Creative Commons Attribution License, which permits unrestricted use, distribution, and reproduction in any medium, provided the original author and source are credited. 
Citation: Zaichick V, Zaichick S (2017) Age-Related Changes of Some Trace Element Contents in Intact Thyroid of Females Investigated by Energy Dispersive X-Ray Fluorescent Analysis. Trends Geriatr Healthc 1(1):31-38

crease of the intracellular ROS scavenging [7]. Oxidative damage to cellular macromolecules which induce cancer can also arise through overproduction of ROS and faulty antioxidant and/or DNA repair mechanisms [8]. Overproduction of ROS is associated with inflammation, radiation, and some other factors, including overload of some trace elements, in both blood and certain tissues, or deficiency of other trace elements with antioxidant properties [9-15]. Studies have shown that the imbalance in the composition of trace elements may cause different types of pathology. The importance of appropriate levels of many trace elements is indisputable, due to their beneficial roles when in specific concentration ranges, while on the other hand they can cause toxic effects with excessively high or low concentrations [12].

In our previous studies [16-24] the high mass fraction of I and some other trace element were observed in intact human thyroid gland when compared with their levels in non-thyroid soft tissues of the human body. However, some questions about the age-dependence of trace element mass fraction in thyroid of adult and, particularly, elderly females still remain unanswered. One valuable way to elucidate the situation is to compare the mass fractions of trace elements in young adult (the control group) with those in older adult and geriatric thyroid. The findings of the excess or deficiency of trace element contents in thyroid and the perturbations of their relative proportions in glands of adult and elderly females, may give an indication of their role in a higher prevalence of thyroid dysfunction in the elderly.

The reliable data on trace element mass fractions in normal geriatric thyroid is apparently extremely limited. There are many studies regarding trace element content in human thyroid, using chemical techniques and instrumental methods [25-30]. However, the majority of these data are based on measurements of processed tissue and in many studies tissue samples are shed before analysis. In other cases, thyroid samples are treated with solvents (distilled water, ethanol etc) and then are dried at a high temperature for many hours. There is evidence that certain quantities of trace elements are lost as a result of such treatment [31-33]. Moreover, only a few of these studies employed quality control using Certified/Standard Reference Materials (CRM/SRM) for determination of the trace element mass fractions.

This work had three aims. The primary purpose of this study was to determine reliable values for the Bromine $(\mathrm{Br})$, Copper ( $\mathrm{Cu})$, Iron (Fe), Rubidium (Rb), Strontium (Sr), and Zinc (Zn) mass fractions in the normal (intact) thyroid of subjects ranging from children to elderly females using $109 \mathrm{Cd}$ radionuclide-induced energy-dispersive X-ray fluorescence analysis (109 Cd EDXRF). The second aim was to compare the $\mathrm{Br}, \mathrm{Cu}, \mathrm{Fe}, \mathrm{Rb}, \mathrm{Sr}$, and $\mathrm{Zn}$ mass fractions in thyroid gland of age group 2 (adults and elderly persons aged 41 to 87 years), with those of group 1 (from 3.5 to 40 years), and the final aim was to estimate the inter-correlations of trace elements in normal thyroid of females. All studies were approved by the Ethical Committee of the Medical Radiological Research Center.

\section{Materials and Methods}

Samples of the human thyroid were obtained from randomly selected autopsy specimens of 33 females (European-Caucasian) aged 3.5 to 87 years. All the deceased were citizens of Obninsk and had undergone routine autopsy at the Forensic Medicine Department of City Hospital, Obninsk. Age ranges for subjects were divided into two age groups, with group 1, 3.5-40 years (30.9 \pm 3.1 years, $\mathrm{M} \pm \mathrm{SEM}, \mathrm{n}=11$ ) and group 2, 41-87 years $(66.3 \pm 2.7$ years, $M \pm S E M, n=22)$. These groups were selected to reflect the condition of thyroid tissue in the children, teenagers, young adults and first period of adult life (group 1) and in the second period of adult life as well as in old age (group 2). The available clinical data were reviewed for each subject. None of the subjects had a history of an intersex condition, endocrine disorder, or other chronic disease that could affect the normal development of the thyroid. None of the subjects were receiving medications or used any supplements known to affect thyroid trace element contents. The typical causes of sudden death of most of these subjects included trauma or suicide and also acute illness (cardiac insufficiency, stroke, embolism of pulmonary artery, alcohol poisoning). All right lobes of thyroid glands were divided into two portions using a titanium scalpel [34]. One tissue portion was reviewed by an anatomical pathologist while the other was used for the trace element content determination. A histological examination was used to control the age norm conformity as well as the unavailability of microadenomatosis and latent cancer.

After the samples intended for chemical element analysis were weighed, they were transferred to $-20{ }^{\circ} \mathrm{C}$ and stored until the day of transportation in the Medical Radiological Research Center, Obninsk, where all samples were freeze-dried and homogenized [35]. The pounded sample weighing about $8 \mathrm{mg}$ was applied to the piece of Scotch tape serving as an adhesive fixing backing [36,37].

To determine the contents of the elements by comparison with a known standard, aliquots of commercial, chemically pure compounds were used [38]. The micro liter standards were placed on disks made of thin, ashfree filter papers fixed on the Scotch tape pieces and dried in a vacuum. Ten subsamples of the Certified Reference Material (CRM) IAEA H-4 (animal muscle) weighing about $8 \mathrm{mg}$ were analyzed to estimate the precision and accuracy of results. The CRM IAEA H-4 subsamples were prepared in the same way as the samples of dry homogenized thyroid tissue. 
Citation: Zaichick V, Zaichick S (2017) Age-Related Changes of Some Trace Element Contents in Intact Thyroid of Females Investigated by Energy Dispersive X-Ray Fluorescent Analysis. Trends Geriatr Healthc 1(1):31-38

The facility for EDXRF included an annular $109 \mathrm{Cd}$ source with an activity of $2.56 \mathrm{GBq}, \mathrm{Si}(\mathrm{Li})$ detector and portable multichannel analyzer combined with a PC. Its resolution was $270 \mathrm{eV}$ at the $5.9 \mathrm{keV}$ line of $55 \mathrm{Fe}$-source. The duration of the $\mathrm{Br}, \mathrm{Cu}, \mathrm{Fe}, \mathrm{Rb}, \mathrm{Sr}$, and $\mathrm{Zn}$ measurements was $60 \mathrm{~min}$. The intensity of $\mathrm{Ka}$-line of $\mathrm{Br}, \mathrm{Cu}, \mathrm{Fe}$, $\mathrm{Rb}, \mathrm{Sr}$, and $\mathrm{Zn}$ for samples and standards was estimated on calculation basis of the total area of the corresponding photo peak in the spectra. The trace element content was calculated by the relative way of comparing between intensities of $\mathrm{Ka}$-lines for samples and standards. Details of the sample preparation, the facility and method of analysis were presented in our previous publication $[36,37]$.

All thyroid samples were prepared in duplicate and

Table 1: EDXRF data $\mathrm{Br}, \mathrm{Fe}, \mathrm{Rb}, \mathrm{Sr}$, and $\mathrm{Zn}$ contents in the IAEA H-4 (animal muscle) reference material compared to certified values ( $\mathrm{mg} / \mathrm{kg}$, dry mass basis).

\begin{tabular}{|c|c|c|c|c|}
\hline \multirow[t]{2}{*}{ Element } & \multicolumn{3}{|c|}{ Certified values } & \multirow{2}{*}{$\begin{array}{l}\text { This work results } \\
\text { Mean } \pm \text { SD }\end{array}$} \\
\hline & Mean & $\begin{array}{l}95 \% \\
\text { confidence } \\
\text { interval }\end{array}$ & Type & \\
\hline $\mathrm{Br}$ & 4.1 & $3.5-4.7$ & C & $5.0 \pm 1.2$ \\
\hline $\mathrm{Cu}$ & 4 & $3.6-4.3$ & C & $3.9 \pm 1.1$ \\
\hline $\mathrm{Fe}$ & 49 & $47-51$ & C & $48 \pm 9$ \\
\hline $\mathbf{R b}$ & 18 & $17-20$ & C & $22 \pm 4$ \\
\hline $\mathrm{Sr}$ & 0.1 & - & $\mathrm{N}$ & $<1$ \\
\hline Zn & 86 & $83-90$ & C & $90 \pm 5$ \\
\hline
\end{tabular}

Mean: Arithmetical mean; SD: Standard Deviation; C: Certified values; N: Non-certified values. mean values of trace element contents were used in final calculation. Using Microsoft Office Excel, a summary of the statistics, including, arithmetic mean, and standard deviation, standard error of mean, minimum and maximum values, median, percentiles with 0.025 and 0.975 levels was calculated for trace element contents. The reliability of difference in the results between two age groups was evaluated by the parametric Student's t-test and non-parametric Wilcoxon-Mann-Whitney U-test. For the construction of "age-trace element mass fraction" diagrams and the estimation of the Pearson correlation coefficient between age and trace element mass fraction as well as between different trace elements the Microsoft Office Excel programs were also used.

\section{Results}

Table 1 depicts our data for 5 trace elements in ten sub-samples of CRM IAEA H-4 (animal muscle) and the certified values of this material.

Table 2 represents certain statistical parameters (arithmetic mean, standard deviation, standard error of mean, minimal and maximal values, median, percentiles with 0.025 and 0.975 levels) of the $\mathrm{Br}, \mathrm{Cu}, \mathrm{Fe}, \mathrm{Rb}, \mathrm{Sr}$, and $\mathrm{Zn}$ mass fractions in intact (normal) thyroid of females.

The comparison of our results with published data for the $\mathrm{Br}, \mathrm{Cu}, \mathrm{Fe}, \mathrm{Rb}, \mathrm{Sr}$, and $\mathrm{Zn}$ contents in the human thyroid is shown in Table 3. To estimate the effect of age on the trace element contents we examined two age groups, described above (Table 4).

Table 2: Some statistical parameters of $\mathrm{Br}, \mathrm{Cu}, \mathrm{Fe}, \mathrm{Rb}, \mathrm{Sr}$, and $\mathrm{Zn}$ mass fraction (mg/kg, dry mass basis) in intact thyroid of female.

\begin{tabular}{|c|c|c|c|c|c|c|c|c|c|}
\hline Gender & Element & Mean & SD & SEM & Min & Max & Median & P 0.025 & P 0.975 \\
\hline Females & $\mathrm{Br}$ & 20.4 & 13.4 & 2.6 & 1.4 & 54.1 & 16.3 & 4.52 & 52.2 \\
\hline \multirow[t]{5}{*}{$n=33$} & $\mathrm{Cu}$ & 4.18 & 1.72 & 0.43 & 0.5 & 6.5 & 4.05 & 1.18 & 6.5 \\
\hline & $\mathrm{Fe}$ & 223 & 104 & 21 & 84 & 512 & 191 & 87.6 & 442 \\
\hline & $\mathrm{Rb}$ & 6.64 & 2.47 & 0.48 & 2.2 & 12.8 & 6.38 & 3.08 & 11.7 \\
\hline & $\mathrm{Sr}$ & 4.67 & 3.11 & 0.78 & 0.65 & 10.9 & 4.4 & 0.82 & 10.8 \\
\hline & $\mathrm{Zn}$ & 89 & 43 & 8.4 & 6.1 & 166 & 88.1 & 6.16 & 156 \\
\hline
\end{tabular}

M: Arithmetic mean; SD: Standard Deviation; SEM: Standard Error of Mean; Min: Minimum value; Max: Maximum value; P 0.025: Percentile with 0.025 level; P 0.975: Percentile with 0.975 level.

Table 3: Median, minimum and maximum value of means $\mathrm{Br}, \mathrm{Cu}, \mathrm{Fe}, \mathrm{Rb}, \mathrm{Sr}$, and $\mathrm{Zn}$ contents in normal thyroid according to data from the literature in comparison with our results ( $\mathrm{mg} / \mathrm{kg}$, dry mass basis).

\begin{tabular}{|l|l|l|l|l|}
\hline Element & \multicolumn{2}{|l|}{ Published data [Reference } & \multicolumn{2}{l|}{ This work } \\
\hline & Median of means $(\mathbf{n})^{*}$ & $\begin{array}{l}\text { Minimum of means } \\
\text { M or M } \pm \text { SD, }(\mathbf{n})^{* *}\end{array}$ & $\begin{array}{l}\text { Maximum of means } \\
\text { M or M } \pm \text { SD, (n) }\end{array}$ & M \pm SD \\
\hline $\mathbf{B r}$ & $18.1(11)$ & $5.12(44)[25]$ & $284 \pm 44(14)[26]$ & $20 \pm 13$ \\
\hline $\mathbf{C u}$ & $6.1(57)$ & $1.42(120)[27]$ & $220 \pm 22(10)[28]$ & $4.2 \pm 1.7$ \\
\hline $\mathbf{F e}$ & $252(21)$ & $56(120)[27]$ & $2444 \pm 700(14)[26]$ & $223 \pm 104$ \\
\hline $\mathbf{R b}$ & $12.3(9)$ & $\leq 0.85(29)[29]$ & $294 \pm 191(14)[26]$ & $6.6 \pm 2.5$ \\
\hline $\mathbf{S r}$ & $0.73(9)$ & $0.55 \pm 0.26(21)[30]$ & $46.8 \pm 4.8(4)[28]$ & $4.7 \pm 3.1$ \\
\hline $\mathbf{Z n}$ & $118(51)$ & $32(120)[27]$ & $820 \pm 204(14)[26]$ & $89 \pm 43$ \\
\hline
\end{tabular}

M: Arithmetic mean; SD: Standard Deviation; $(n)^{\star}$ : Number of all references; $(n){ }^{* *}$ : Number of samples. 
Citation: Zaichick V, Zaichick S (2017) Age-Related Changes of Some Trace Element Contents in Intact Thyroid of Females Investigated by Energy Dispersive X-Ray Fluorescent Analysis. Trends Geriatr Healthc 1(1):31-38
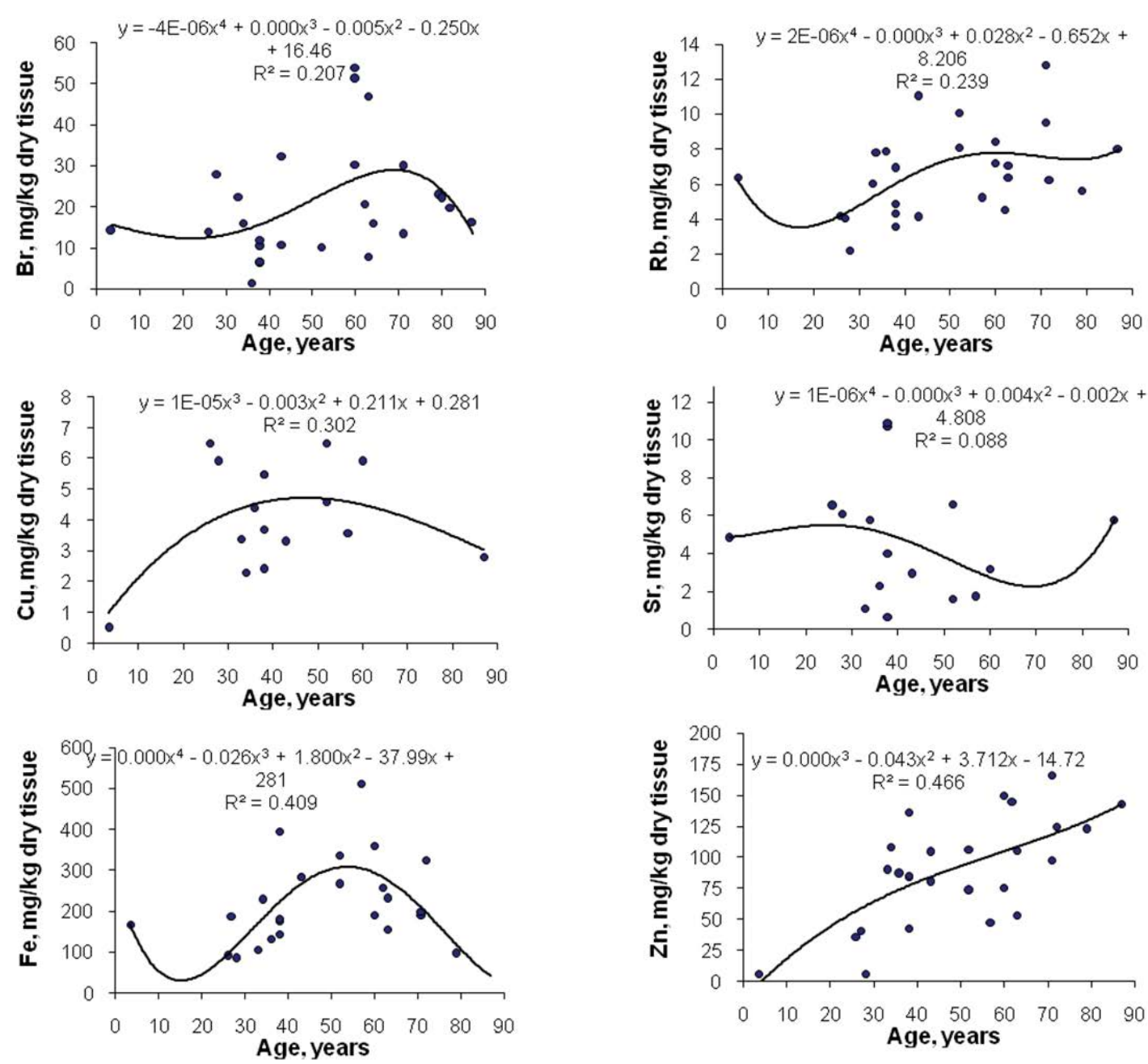

Figure 1: Data sets of individual $\mathrm{Br}, \mathrm{Cu}, \mathrm{Fe}, \mathrm{Rb}, \mathrm{Sr}$, and $\mathrm{Zn}$ mass fraction values in intact thyroid of females and their trend lines.

Table 4: Differences between mean values (M $\pm \mathrm{SEM}$ ) of $\mathrm{Br}, \mathrm{Cu}, \mathrm{Fe}, \mathrm{Rb}, \mathrm{Sr}$, and $\mathrm{Zn}$ mass fraction (mg/kg, dry mass basis) in normal female thyroid of two Age Groups (AG).

\begin{tabular}{|c|c|c|c|c|c|}
\hline \multirow[t]{2}{*}{ Element } & \multicolumn{4}{|c|}{ Female thyroid tissue } & \multirow{2}{*}{$\begin{array}{l}\text { Ratio } \\
\text { AG2 to AG1 }\end{array}$} \\
\hline & AG1 & AG2 & t-test & U-test & \\
\hline & $3.5-40$ years & $41-87$ years & $p \leq$ & $p$ & \\
\hline & $n=11$ & $n=22$ & & & \\
\hline $\mathrm{Br}$ & $13.1 \pm 2.5$ & $24.7 \pm 3.5$ & 0.0112 & $\leq 0.01$ & 1.89 \\
\hline $\mathrm{Cu}$ & $4.01 \pm 0.60$ & $4.45 \pm 0.61$ & 0.616 & $>0.05$ & 1.11 \\
\hline $\mathrm{Fe}$ & $172 \pm 26$ & $263 \pm 27$ & 0.0240 & $\leq 0.01$ & 1.53 \\
\hline $\mathbf{R b}$ & $5.30 \pm 0.55$ & $7.62 \pm 0.64$ & 0.0112 & $\leq 0.01$ & 1.44 \\
\hline $\mathrm{Sr}$ & $5.29 \pm 1.12$ & $3.63 \pm 0.86$ & 0.262 & $>0.05$ & 0.69 \\
\hline $\mathrm{Zn}$ & $65.6 \pm 12.7$ & $106.2 \pm 9.3$ & 0.0176 & $\leq 0.01$ & 1.62 \\
\hline
\end{tabular}

M: Arithmetic mean; SEM: Standard Error of Mean; $t$-test: Student's $t$-test; U-test: Wilcoxon-Mann-Whitney U-test; Statistically significant values are in bold.

Table 5: Correlations between age and chemical element mass fractions in the intact thyroid of female ( $r$-coefficient of correlation).

\begin{tabular}{|l|l|l|l|l|l|l|}
\hline Element & $\mathbf{B r}$ & $\mathbf{C u}$ & $\mathbf{F e}$ & $\mathbf{R b}$ & $\mathbf{S r}$ & $\mathbf{Z n}$ \\
\hline Age & 0.246 & 0.184 & 0.27 & $0.393^{\mathrm{a}}$ & -0.095 & $0.670^{\mathrm{c}}$ \\
\hline
\end{tabular}

Statistically significant values: ${ }^{a} p \leq 0.05 ;{ }^{c} p \leq 0.001$.
In addition, the Pearson correlation coefficient between age and trace element mass fraction was calculated (Table 5). Figure 1 shows the individual data sets for the $\mathrm{Br}, \mathrm{Cu}, \mathrm{Fe}, \mathrm{Rb}, \mathrm{Sr}$, and $\mathrm{Zn}$ mass fraction in all samples of thyroid, and also lines of trend with age. 
Citation: Zaichick V, Zaichick S (2017) Age-Related Changes of Some Trace Element Contents in Intact Thyroid of Females Investigated by Energy Dispersive X-Ray Fluorescent Analysis. Trends Geriatr Healthc 1(1):31-38

Table 6: Inter correlations of the chemical element mass fractions in the intact thyroid of female ( $r$-coefficient of correlation).

\begin{tabular}{|l|l|l|l|l|l|l|}
\hline Element & $\mathbf{B r}$ & $\mathbf{C u}$ & $\mathbf{F e}$ & $\mathbf{R b}$ & $\mathbf{S r}$ & $\mathbf{Z n}$ \\
\hline $\mathbf{B r}$ & $\mathbf{1 . 0 0}$ & 0.173 & 0.255 & 0.062 & -0.200 & 0.023 \\
\hline $\mathbf{C u}$ & 0.173 & $\mathbf{1 . 0 0}$ & 0.048 & 0.009 & 0.249 & 0.024 \\
\hline $\mathbf{F e}$ & 0.255 & 0.048 & $\mathbf{1 . 0 0}$ & 0.185 & $-0.349^{\mathrm{a}}$ & 0.213 \\
\hline $\mathbf{R b}$ & 0.062 & 0.009 & 0.185 & $\mathbf{1 . 0 0}$ & -0.116 & $0.481^{\mathrm{b}}$ \\
\hline $\mathbf{S r}$ & -0.200 & 0.249 & $-0.349^{\mathrm{a}}$ & -0.116 & $\mathbf{1 . 0 0}$ & -0.001 \\
\hline $\mathbf{Z n}$ & 0.023 & 0.024 & 0.213 & $0.481^{\mathrm{b}}$ & -0.001 & $\mathbf{1 . 0 0}$ \\
\hline
\end{tabular}

Statistically significant values: ${ }^{\mathrm{a}} p \leq 0.05 ;{ }^{\mathrm{b}} p \leq 0.01$.

The data of inter-correlation calculations (values of $\mathrm{r}$-coefficient of correlation) including all trace elements identified by us are presented in Table 6 .

\section{Discussion}

A set of existing international CRM prepared from the soft tissues of humans and animals is extremely limited. As is was previously discussed [36] $97 \%$ of the self-absorption in the dry sample of human tissue is due to the content of bulk elements $(\mathrm{C}, \mathrm{N}, \mathrm{O}, \mathrm{P}, \mathrm{S})$ and main electrolytes $(\mathrm{Ca}, \mathrm{Cl}, \mathrm{Na})$. The content of these elements and the mass density of muscle and thyroid in humans are virtually identical [39]. Accordingly, the use of CRM IAEA H-4 as a CRM for the analysis of samples of thyroid tissue can be seen as quite acceptable. Good agreement of the $\mathrm{Br}, \mathrm{Cu}, \mathrm{Fe}, \mathrm{Rb}, \mathrm{Sr}$, and $\mathrm{Zn}$ contents analyzed by EDX$\mathrm{RF}$ with the certified data of CRM IAEA H-4 (Table 1) indicates an acceptable accuracy of the results obtained in the study of trace elements of the thyroid presented in Table 2, Table 3, Table 4 and Table 5.

The obtained means for $\mathrm{Br}, \mathrm{Cu}, \mathrm{Fe}, \mathrm{Rb}, \mathrm{Sr}$, and $\mathrm{Zn}$ mass fraction, as shown in Table 3 , agree well with the medians of mean values cited by other researches for the human thyroid, including samples received from persons who died from different non-thyroid diseases [24-30]. A number of values for chemical element mass fractions were not expressed on a dry mass basis by the authors of the cited references. However, we calculated these values using published data for water (75\%) [40] and ash (4.16\% on dry mass basis) [41] contents in thyroid of adults.

A strongly pronounced tendency of age-related increase in Br mass fraction was observed in thyroid (Table 4). In second group of females with mean age 66.3 years the mean $\mathrm{Br}$ mass fraction in thyroids was almost 2 times higher than in thyroids of the first age group (mean age 30.9 years). A modest tendency of age-related increase in $\mathrm{Fe}, \mathrm{Rb}$, and $\mathrm{Zn}$ mass fractions was also observed in thyroid (Table 4). The Fe, $\mathrm{Rb}$, and $\mathrm{Zn}$ mass fraction growth in thyroid tissue for ages between 30.9 (age group 1) and 66.3 (age group 2) years averaged 53\%, 44\%, and 62\%, respectively. There were no statistically significant differences between the $\mathrm{Cu}$ and $\mathrm{Sr}$ mass fractions within different age-groups.
Age-dependence of $\mathrm{Br}$ and $\mathrm{Fe}$ mass fractions found using the comparison between results for two age groups was not confirmed when the Pearson correlation coefficient between age and mass fractions of these elements was calculated (Table 5). Thus, the questions about the $\mathrm{Br}$ and Fe mass fraction dependence on age stay open and need a similarly future study with larger sample size. No published data referring to age-related changes of $\mathrm{Br}, \mathrm{Cu}, \mathrm{Fe}, \mathrm{Rb}, \mathrm{Sr}$, and $\mathrm{Zn}$ mass fractions in female thyroid was found.

A significant direct correlation between the $\mathrm{Zn}$ and $\mathrm{Rb}$ mass fractions $(\mathrm{p} \pm 0.01, \mathrm{r}=0.48)$ and an inverse correlation between $\mathrm{Fe}$ and $\mathrm{Sr}$ mass fractions $(\mathrm{p} \pm 0.05, \mathrm{r}=0.35)$ was seen in female thyroid. The interpretation of observed correlations requires further study for a more complete understanding. No correlation was demonstrated between any other chemical elements (Table 5). No published data referring to inter-correlations of $\mathrm{Br}, \mathrm{Cu}, \mathrm{Fe}, \mathrm{Rb}, \mathrm{Sr}$, and $\mathrm{Zn}$ mass fractions in thyroid of females was found.

An age-related increase and excess in $\mathrm{Rb}$ and $\mathrm{Zn}$ mass fractions in thyroid tissue may contribute to harmful effects on the gland. There are good reasons for such speculations since many reviews and numerous papers raise the concern about toxicity and tumorigenesis of the metals $[10,11,42-74]$. Each of the metals is distinct in its primary mode of action. Moreover, there are several forms of synergistic action of the metals as a part of intracellular metabolism, during which several reactive intermediates and byproducts are created $[42,43,48]$. These reactive species are capable of potent and surprisingly selective activation of stress-signaling pathways, inhibition of DNA metabolism, repair, and formation of DNA cross links, which are known to contribute to the development of human cancers $[43,75,76]$. In addition to genetic damage via both oxidative and nonoxidative (DNA adducts) mechanisms, metals can also cause significant changes in DNA methylation and histone modifications, leading to alterations in gene expression $[44,46,75]$. In vitro and animal tumorigenic studies provided strong support for the idea that metals can also act as co-carcinogens in combination with nonmetal carcinogens [75].

All the deceased were citizens of Obninsk. Obninsk is the small nonindustrial city not far from Moscow in unpolluted area. None of those who died a sudden death had suffered from any systematic or chronic disorders before. The normal state of thyroid was confirmed by morphological study. Thus, our data for $\mathrm{Br}, \mathrm{Cu}, \mathrm{Fe}, \mathrm{Rb}$, $\mathrm{Sr}$, and $\mathrm{Zn}$ mass fractions in intact thyroid may serve as indicative normal values for females of urban population of the Russian Central European region.

\section{Conclusion}

The $109 \mathrm{Cd}$ radionuclide-induced energy-dispersive $\mathrm{X}$-ray fluorescence analysis is a useful analytical tool for 
Citation: Zaichick V, Zaichick S (2017) Age-Related Changes of Some Trace Element Contents in Intact Thyroid of Females Investigated by Energy Dispersive X-Ray Fluorescent Analysis. Trends Geriatr Healthc 1(1):31-38

the non-destructive determination of trace element content in the thyroid tissue samples. This method allows determine means for $\mathrm{Br}, \mathrm{Cu}, \mathrm{Fe}, \mathrm{Rb}, \mathrm{Sr}$, and $\mathrm{Zn}$ (6 trace elements).

Our data reveal that there is strongly pronounced tendency of increase in $\mathrm{Rb}$ and $\mathrm{Zn}$ mass fraction in the normal thyroid of female during a lifespan. Therefore, a goitrogenic and tumorogenic effect of excessive $\mathrm{Rb}$ and $\mathrm{Zn}$ level in the thyroid of old females may be assumed.

\section{References}

1. Gesing A (2015) The thyroid gland and the process of aging. Thyroid Research 8: 8.

2. Mitrou P, Raptis SA, Dimitriadis G (2011) Thyroid disease in older people. Maturitas 70: 5-9.

3. Kwong N, Medici M, Angell TE, et al. (2015) The Influence of Patient Age on Thyroid Nodule Formation, Multinodularity, and Thyroid Cancer Risk. J Clin Endocrinol Metab 100: 4434-4440.

4. Mazzaferri EL (1993) Management of a solitary thyroid nodule. N Engl J Med 328: 553-559.

5. Smailyte G, Miseikyte-Kaubriene E, Kurtinaitis J (2006) Increasing thyroid cancer incidence in Lithuania in 19782003. BMC Cancer 6: 284.

6. Olinski R, Siomek A, Rozalski R, et al. (2007) Oxidative damage to DNA and antioxidant status in aging and age-related diseases. Acta Biochim Pol 54: 11-26.

7. Minelli A, Bellezza I, Conte C, et al. (2009) Oxidative stress-related aging: A role for prostate cancer? Biochim Biophys Acta 1795: 83-91.

8. Klaunig JE, Kamendulis LM, Hocevar BA (2010) Oxidative stress and oxidative damage in carcinogenesis. Toxicol Pathol 38: 96-109.

9. Jarup L (2003) Hazards of heavy metal contamination. $\mathrm{Br}$ Med Bull 68: 167-182.

10. Zaichick V, Zaichick S (1999) Role of zinc in prostate cancerogenesis. In: Anke M, Mengen und Spurenelemente, 19 Arbeitstagung. Friedrich-Schiller-Universitat, Jena, 104-115.

11. Zaichick V (2004) INAA and EDXRF applications in the age dynamics of $\mathrm{Zn}$ content and distribution in the normal human prostate. J Radioanal Nucl Chem 262: 229-234.

12. Zaichick V (2006) Medical elementology as a new scientific discipline. J Radioanal Nucl Chem 269: 303-309.

13. Toyokuni $S$ (2008) Molecular mechanisms of oxidative stress-induced carcinogenesis: from epidemiology to oxygenomics. IUBMB Life 60: 441-447.

14. Gupte A, Mumper RJ (2009) Elevated copper and oxidative stress in cancer cells as a target for cancer treatment. Cancer Treat Rev 35: 32-46.

15. Lee JD, Wu SM, Lu LY, et al. (2009) Cadmium concentration and metallothionein expression in prostate cancer and benign prostatic hyperplasia of humans. J Formos Med Assoc 108: 554-559.

16. Zaichick VYe, Tsyb AF, Vtyurin BM (1995) Trace elements and thyroid cancer. Analyst 120: 817-821.
17. Zaichick V, Choporov Yu (1996) Determination of the natural level of human intra-thyroid iodine by instrumental neutron activation analysis. J Radioanal Nucl Chem 207: 153-161.

18. Zaichick V, Zaichick S (1997) Normal human intrathyroidal iodine. Sci Total Environ 206: 39-56.

19. Zaichick V (1998) lodine excess and thyroid cancer. J Trace Elements in Experimental Medicine 11: 508-509.

20. Zaichick V (1998) In vivo and in vitro application of energy-dispersive XRF in clinical investigations: experience and the future. J Trace Elements in Experimental Medicine 11: 509-510.

21. Zaichick V, Iljina T (1998) Dietary iodine supplementation effect on the rat thyroid 131 l blastomogenic action. In: Anke M, Die Bedentung der Mengen- und Spurenelemente, 18 Arbeitstangung. Friedrich-Schiller-Universitat, Jena, 294-306.

22. Zaichick V, Zaichick S (1999) Energy-dispersive X-ray fluorescence of iodine in thyroid puncture biopsy specimens. J Trace and Microprobe Techniques 17: 219-232.

23. Zaichick V (1999) Human intrathyroidal iodine in health and non-thyroidal disease. In: Abdulla M, New aspects of trace element research. Smith-Gordon and Nishimura London and Tokyo, 114-119.

24. Zaichick V (2000) Relevance of and potentiality for in vivo intrathyroidal iodine determination. In: Yasumura S, In Vivo Body Composition Studies. Annals of the New York Academy of Sciences 904: 630-631.

25. Zhu H, Wang N, Zhang Y, et al. (2010) Element contents in organs and tissues of Chinese adult men. Health Phys 98: 61-73.

26. Salimi J, Moosavi K, Vatankhah S, et al. (2004) Investigation of heavy trace elements in neoplastic and non-neoplastic human thyroid tissue: A study by proton - induced X-ray emissions. Iran J Radiat Res 1: 211-216.

27. Ataullakhanov IA (1969) Age changes in the content of manganese, cobalt, copper, zinc and iron in the endocrine glands of women. Probl Endokrinol (Mosk) 15: 98-102.

28. Reddy SB, Charles MJ, Kumar MR, et al. (2002) Trace elemental analysis of adenoma and carcinoma thyroid by PIXE method. Nucl Instr Meth Phys Res B 196: 333-339.

29. Boulyga SF, Zhuk IV, Lomonosova EM, et al. (1997) Determination of microelements in thyroids of the inhabitants of Belarus by neutron activation analysis using the k0-method. J Radioanal Nucl Chem 222: 11-14.

30. Tipton Ih, Cook MJ (1963) Trace elements in human tissue. II. Adult subjects from the United States. Health Phys 9: 103-145.

31. Zaichick V (1997) Sampling, sample storage and preparation of biomaterials for INAA in clinical medicine, occupational and environmental health. In: Harmonization of Health-Related Environmental Measurements Using Nuclear and Isotopic Techniques. IAEA, Vienna, 123-133.

32. Zaichick V (2004) Losses of chemical elements in biological samples under the dry ashing process. Trace Elements in Medicine 5: 17-22.

33. Zaichick V, Zaichick S (2000) INAA applied to halogen $(\mathrm{Br}$ and I) stability in long-term storage of lyophilized biological materials. J Radioanal Nucl Chem 244: 279-281. 
Citation: Zaichick V, Zaichick S (2017) Age-Related Changes of Some Trace Element Contents in Intact Thyroid of Females Investigated by Energy Dispersive X-Ray Fluorescent Analysis. Trends Geriatr Healthc 1(1):31-38

34. Zaichick V, Zaichick S (1996) Instrumental effect on the contamination of biomedical samples in the course of sampling. The Journal of Analytical Chemistry 51: 1200-1205.

35. Zaichick V, Zaichick S (1997) A search for losses of chemical elements during freeze-drying of biological materials. J Radioanal Nucl Chem 218: 249-253.

36. Zaichick S, Zaichick V (2010) Method and portable facility for energy-dispersive X-ray fluorescent analysis of zinc content in needle-biopsy specimens of prostate. X-Ray Spectrom 39: 83-89.

37. Zaichick S, Zaichick V (2011) The Br, Fe, Rb, Sr, and Zn content and interrelation in intact and morphologic normal prostate tissue of adult men investigated by energy dispersive X-ray fluorescent analysis. X-Ray Spectrom 40: 464469.

38. Zaichick V (1995) Applications of synthetic reference materials in the medical Radiological Research Centre. Fresenius J Anal Chem 352: 219-223.

39. (1974) International Commission on Radiological Protection (ICRP). Report of the Task Group on reference Man. Pergamon Press, Oxford.

40. Katoh Y, Sato T, Yamamoto Y (2002) Determination of multielement concentrations in normal human organs from the Japanese. Biol Trace Elem Res 90: 57-70.

41. Schroeder HA, Tipton IH, Nason AP (1972) Trace metals in man: strontium and barium. J Chronic Dis 25: 491-517.

42. Sunderman FW (1979) Mechanisms of metal carcinogenesis. Biol Trace Elem Res 1: 63-86.

43. Snow ET (1992) Metal carcinogenesis: mechanistic implications. Pharmacol Ther 53: 31-65.

44. Toyokuni S (2009) Role of iron in carcinogenesis: cancer as a ferrotoxic disease. Cancer Sci 100: 9-16.

45. Martinez-Zamudio R, Ha HC (2011) Environmental epigenetics in metal exposure. Epigenetics 6: 820-827.

46. Tokar EJ, Benbrahim-Tallaa L, Waalkes MP (2011) Metal ions in human cancer development. Met lons Life Sci 8: 375-401.

47. Tchounwou PB, Yedjou CG, Patlolla AK, et al. (2012) Heavy metal toxicity and the environment. Molecular, Clinical and Environmental Toxicology 101: 133-164.

48. Koedrith P, Kim H, Weon JI, et al. (2013) Toxicogenomic approaches for understanding molecularmechanisms of heavy metal mutagenicity and carcinogenicity. Int $\mathrm{J}$ Hyg Environ Health 216: 587-598.

49. Tabrez S, Priyadarshini M, Priyamvada S, et al. (2014) Gene-environment interactions in heavy metal and pesticide carcinogenesis. Mutat Res Genet Toxicol Environ Mutagen 760: 1-9.

50. Zaichick S, Zaichick V (2011) INAA application in the age dynamics assessment of $\mathrm{Br}, \mathrm{Ca}, \mathrm{Cl}, \mathrm{K}, \mathrm{Mg}, \mathrm{Mn}$, and $\mathrm{Na}$ content in the normal human prostate. J Radioanal Nucl Chem 288: 197-202.

51. Zaichick S, Zaichick V (2011) The effect of age on Ag, Co, $\mathrm{Cr}, \mathrm{Fe}, \mathrm{Hg}, \mathrm{Sb}, \mathrm{Sc}, \mathrm{Se}$, and $\mathrm{Zn}$ contents in intact human prostate investigated by neutron activation analysis. App Radiat Isot 69: 827-833.
52. Zaichick V, Nosenko S, Moskvina I (2012) The effect of age on 12 chemical element contents in the intact prostate of adult men investigated by inductively coupled plasma atomic emission spectrometry. Biol Trace Elem Res 147: 49-58.

53. Zaichick S, Zaichick V, Nosenko S, et al. (2012) Mass Fractions of 52 Trace Elements and Zinc Trace Element Content Ratios in Intact Human Prostates Investigated by Inductively Coupled Plasma Mass Spectrometry. Biol Trace Elem Res 149: 171-183.

54. Zaichick V, Zaichick S (2014) INAA application in the assessment of chemical element mass fractions in adult and geriatric prostate glands. Appl Radiat Isot 90: 62-73.

55. Zaichick V, Zaichick S (2014) Determination of trace elements in adults and geriatric prostate combining neutron activation with inductively coupled plasma atomic emission spectrometry. Open Journal of Biochemistry 1: 16-33.

56. Zaichick V, Zaichick S (2014) Use of INAA and ICP-MS for the assessment of trace element mass fractions in adult and geriatric prostate. J Radioanal Nucl Chem 301: 383397.

57. Zaichick V, Zaichick S (2014) Age-related histological and zinc content changes in adult nonhyperplastic prostate glands. Age (Dordr) 36: 167-181.

58. Zaichick V, Zaichick S (2015) Differences and relationships between morphometric parameters and zinc content in nonhyperplastic and hyperplastic prostate glands. BJMMR 8: 692-706.

59. Zaichick V, Zaichick S, Davydov G (2015) Differences between chemical element contents in hyperplastic and nonhyperplastic prostate glands investigated by neutron activation analysis. Biol Trace Elem Res 164: 25-35.

60. Zaichick S, Zaichick V (2015) Prostatic Tissue Level of some Androgen Dependent and Independent Trace Elements in Patients with Benign Prostatic Hyperplasia. Androl Gynecol: Curr Res 3: 3.

61. Zaichick V, Zaichick S (2016) The Bromine, Calcium, Potassium, Magnesium, Manganese, and Sodium Contents in Adenocarcinoma of Human Prostate Gland. J Hematology and Oncology Research 2: 1-12.

62. Zaichick V, Zaichick S (2016) Trace element contents in adenocarcinoma of human prostate investigated by energy dispersive X-ray fluorescent analysis. Journal of Adenocarcinoma 1: 1-7.

63. Zaichick V, Zaichick S (2016) Trace element contents in adenocarcinoma of the human prostate gland investigated byneutron activation analysis. Cancer Research and Oncology 1: 1-10.

64. Zaichick V, Zaichick S (2016) Variations in concentration and distribution of several androgen-dependent and -independent trace elements in nonhyperplastic prostate gland tissue throughout adulthood. J Androl Gynaecol 4: 1-10.

65. Zaichick V, Zaichick S (2016) Prostatic tissue levels of 43 trace elements in patients with prostate adenocarcinoma. Cancer and Clinical Oncology 5: 79-94.

66. Zaichick V, Zaichick S (2016) Levels of 43 trace elements in hyperplastic prostate tissues. British Journal of Medicine and Medical Research 15: 1-12. 
Citation: Zaichick V, Zaichick S (2017) Age-Related Changes of Some Trace Element Contents in Intact Thyroid of Females Investigated by Energy Dispersive X-Ray Fluorescent Analysis. Trends Geriatr Healthc 1(1):31-38

67. Zaichick V, Zaichick S (2016) Prostatic tissue level of some major and trace elements in patients with BPH. JJ NephroUrol 3: 025.

68. Zaichick V, Zaichick S (2016) Age-related changes in concentration and histological distribution of $\mathrm{Br}, \mathrm{Ca}, \mathrm{Cl}, \mathrm{K}, \mathrm{Mg}$, $\mathrm{Mn}$, and $\mathrm{Na}$ in nonhyperplastic prostate of adults. European Journal of Biology and Medical Science Research 4: 31-48.

69. Zaichick V, Zaichick S (2016) Variations in concentration and histological distribution of $\mathrm{Ag}, \mathrm{Co}, \mathrm{Cr}, \mathrm{Fe}, \mathrm{Hg}, \mathrm{Rb}, \mathrm{Sb}$, $\mathrm{Sc}, \mathrm{Se}$, and $\mathrm{Zn}$ in nonhyperplastic prostate gland throughout adulthood. Jacobs Journal of Cell and Molecular Biology 2: 011.

70. Zaichick V, Zaichick S (2016) Age-related Changes in Concentration and Histological Distribution of 18 Chemical Elements in Nonhyperplastic Prostate of Adults. World Journal of Pharmaceutical and Medical Research 2: 5-18.

71. Zaichick V, Zaichick S (2016) Age-Related Changes in Concentration and Histological Distribution of 54 Trace El- ements in Nonhyperplastic Prostate of Adults. Int Arch Urol Complic 2: 019.

72. Zaichick V, Zaichick S (2016) The Comparison between the contents and interrelationships of 17 chemical elements in normal and cancerous prostate gland. Journal of Prostate Cancer 1: 105.

73. Zaichick V, Zaichick S, Wynchank S (2016) Intracellular zinc excess as one of the main factors in the etiology of prostate cancer. Journal of Analytical Oncology 5: 124-131.

74. Zaichick V, Zaichick S, Rossmann M (2016) Intracellular calcium excess as one of the main factors in the etiology of prostate cancer. AIMS Molecular Science 3: 635-647.

75. Salnikow K, Zhitkovich A (2008) Genetic and epigenetic mechanisms in metal carcinogenesis and cocarcinogenesis: nickel, arsenic, and chromium. Chem Res Toxicol 21: 28-44.

76. Chervona Y, Arita A, Costa M (2012) Carcinogenic metals and the epigenome: understanding the effect of nickel, arsenic, and chromium. Metallomics 4: 619-627. 